\title{
Article \\ Sensitivity Analysis of PROMETHEE II for the Evaluation of Environmental Websites
}

\author{
Katerina Kabassi * $\mathbb{D}$ and Aristotelis Martinis
}

check for

updates

Citation: Kabassi, K.; Martinis, A. Sensitivity Analysis of PROMETHEE II for the Evaluation of Environmental Websites. Appl. Sci. 2021, 11, 9215. https://doi.org/10.3390/app11199215

Academic Editor: Vito Conforti

Received: 27 August 2021

Accepted: 27 September 2021

Published: 3 October 2021

Publisher's Note: MDPI stays neutral with regard to jurisdictional claims in published maps and institutional affiliations.

Copyright: (c) 2021 by the authors. Licensee MDPI, Basel, Switzerland. This article is an open access article distributed under the terms and conditions of the Creative Commons Attribution (CC BY) license (https:/ / creativecommons.org/licenses/by/ $4.0 /)$.

\begin{abstract}
Department of Environment, Ionian University, 29100 Zakynthos, Greece; amartinis@ionio.gr * Correspondence: kkabassi@ionio.gr
\end{abstract}

\begin{abstract}
The quality of content and the attractiveness of an environmental website can create an environmentally friendly attitude before one visits a secured area. However, a website should be evaluated to ensure that its goal is met. For this reason, the websites of environmental content have been evaluated using a combination of AHP and PROMETHEE II. More specifically, the websites of environmental content that have been selected to be evaluated are the websites of the national parks of Italy. The main contribution of the particular paper is on comparing PROMETHEE II with three other common MCDM models (SAW, WPM, TOPSIS) and performing a sensitivity analysis to make the comparison more thorough. As a result, the conclusions drawn by this experiment involve the appropriateness of PROMETHEE II for the ranking of environmental websites as well as the robustness of the different MCDM models. The experiment revealed that the PROMETHEE II model was found to be very effective in ranking environmental websites and is the most robust model compared to the other ones. Furthermore, the evaluation of the websites of national parks in Italy revealed that the electronic presence of national parks is at an early stage.
\end{abstract}

Keywords: environmental awareness; AHP; PROMETHEE II; website evaluation

\section{Introduction}

Several researchers have highlighted the advantages of parks and protected areas, not only for the protection of the environment but for the economic development of the areas as well [1]. Websites constitute the most common way to promote environmental information and promote a national park (NP) as an eco-touristic destination [2,3]. The important role of the websites in the promotion of environmental information has been highlighted by several researchers [4-8]. The information available involves characteristics of a protected area (PA), the landscape, the culture, and generally its profile. The website can influence potential visitors and lead them to form an environmental attitude. However, the confirmation that the goals of the website are met can only be achieved through an evaluation experiment [9].

For the evaluation of websites, several researchers have used criteria [10,11] and some have used Multi-Criteria Decision Making (MCDM) models for combining these criteria in order to evaluate websites in different domains that are related to environmental content $[9,12,13]$. In some cases environmental websites have also been evaluated with the use of MCDM models [9,14]. Previous work on the evaluation of websites of environmental content [14-16] has revealed the criteria and the weights of importance of these criteria using the Analytic Hierarchy Process (AHP) [17,18].

Taking into account the information provided in the previous experiments, in this paper we implement an evaluation experiment of the websites of the NPs in Italy. For this purpose, a combination of AHP with PROMETHEE II (Preference Ranking Organization METHod for Enrichment Evaluations II) [19,20] is used. PROMETHEE has seen much use in environmental management, hydrology and water management, business and financial management, chemistry, logistics and transportation, manufacturing and assembly, energy management, and agriculture [21], but only once before for website evaluation [22]. The 
PROMETHEE II outranking method was adopted for this evaluation experiment to aggregate the opinions of decision-makers that evaluate websites of environmental content. This method is software-driven, user-friendly, provides a direct interpretation of parameters, and analyzes the sensitivity of results.

The combination of AHP with PROMETHEE II has been effectively used mainly in other domains and not for the evaluation of environmental websites (e.g., [23-25]). The only time that this combination has been used for the evaluation of environmental websites was with Kabassi et al. [22], in which the websites of NPs of Greece and Italy were evaluated and compared. However, the main difference of the current work is that we focus on the sensitivity analysis of the application of PROMETHEE II tor the evaluation of environmental websites. The sensitivity analysis can help one draw conclusions on the robustness of the method and the consistency of the results [26]. The robustness is also checked in comparison with other methods such as TOPSIS (Technique for Order of Preference by Similarity to Ideal Solution) [27], SAW (Simple Additive Weighting) [27] and WPM (Weighted Product Model) [28,29].

The main body of the paper is organized as follows: Section 2 presents the materials and methods. More specifically, its subsections present the websites of the PAs and their role in Italy, the criteria used for the evaluation as well as the steps of PROMETHEE II for the evaluation of environmental websites. In Section 3, the results of the application of PROMETHEE II, the comparison of that model with the three other MCDM models, and the sensitivity analysis, are presented. In Section 4, the discussion of this work is done by comparing this work with other similar experiments. In the last section, the conclusions drawn by this work are analyzed, the limitations are given and future work is announced.

\section{Materials and Methods}

This section presents and analyzes the alternative websites of the protected areas in Italy that are evaluated (Section 2.1) and the criteria that are used for the evaluation as well as their weights of importance (Section 2.2). In the last subsection, the application of PROMETHEE II is given in detail (Section 2.3).

\subsection{Protected Areas in Italy and Their Websites}

The creation of the PAs was based on national and European legislation and aimed at protecting the natural and cultural heritage of the country. In Italy, the categories of PAs are as follows: 25 national parks, 147 state-owned natural reserves, 30 state-owned marine reserves, 151 regional natural parks, 419 regional natural reserves, and 576 other protected areas.

The situation of NPs in Italy has never been fully satisfactory, despite the fact that Italy was one of the first countries in Europe to establish a NP (the Gran Paradiso National Park in 1922). Today, Italian NPs cover about $5 \%$ of the country's land (Figure 1). PAs are managed by the Ministry of Environment and there are a total of 3496 PAs in Italy, of which 2621 are Natura 2000 sites and 875 sites are designated under national law.

Since 1997, Italy has implemented the Habitats Directive and designated Natura 2000 sites in the country [30]. Natura 2000 sites are sources or ecosystem services that can prevent the loss of biodiversity [31]. Furthermore, economic development of the areas that support sustainability may also contribute to their preservation. Indeed, as Tomaskinova et al. [32] point out, besides conservation of biodiversity, PAs provides several social and economic advantages that can contribute to the economic development of an area (CEETO, 2018). Schagner et al. [33], argue that PAs are places where the conservation of nature should not only focus on the protection of biodiversity and the environment but should also take recreational co-benefits into account. Moreover, Gantioler et al. [34], and Schirpke et al. [35], report that PAs are responsible not only for protecting the environment but for constituting the area a tourist destination. In this way, they can contribute in the protection of the environment and help the economic empowerment of local communities through the frame of sustainable development. Empirical studies have demonstrated 
that PAs represent an efficient mechanism for combining sustainable land use with socioeconomic development [36-38]. Because of its high naturalness and biodiversity, PAs are becoming increasingly important for recreational opportunity, providing benefits in terms of physical and mental health through outdoor experiences [35,39,40]. However, as highlighted by Dudley [41], in the case of a NP, economic development is mostly supported through tourism. Tourism can contribute effectively to the local and national economies.

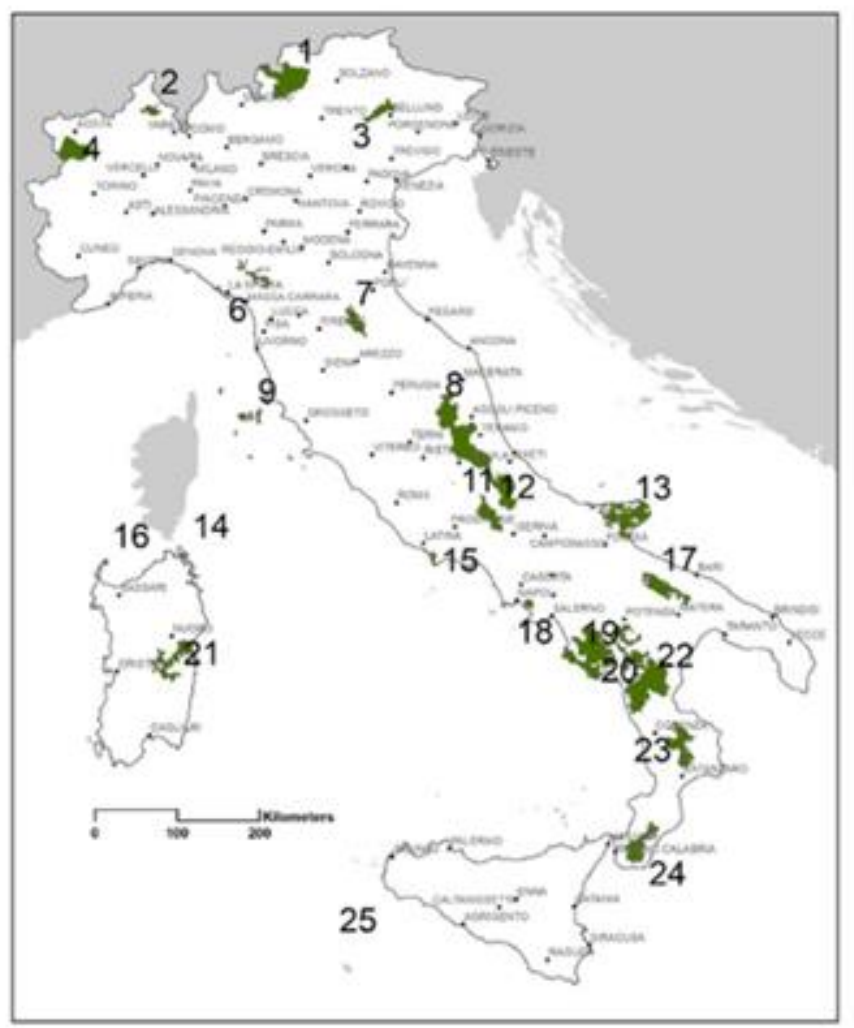

Figure 1. Italian NPs: geographic location (source: http:/ / www.parks.it, accesses on 1 January 2021).

The importance of the websites for promoting ecotourism and improving the electronic presence of national parks and protected areas through the internet is indisputable $[9,28]$. A website may provide a virtual perception of the areas that can expedite the decision to visit an area easier [42]. As a result, Italian NPs were collected (Table 1) and they were evaluated regarding their electronic presence.

The websites of PAMPBs are considered to be the alternatives in our decision making problem.

\subsection{Evaluation Criteria and Weights of Importance Using AHP}

The evaluation of environmental websites is based on the criteria selected from a pool of criteria previously proposed by Tsai, Chou, \& Lai [43]. This selection took place in a previous experiment $[22,28]$ and revealed the following criteria:

c1-Quality of content.

c2-Attractiveness.

c3-Navigability.

c4-Relevancy.

c5-Accessibility.

c6-Responsiveness.

c7-Links.

c8-Multilingualism.

c9-Quality of mobile interactiveness.

c10-Services. 
Table 1. The website of NPs in Italy.

\begin{tabular}{|c|c|c|}
\hline & National Park & Website \\
\hline A1 & Parco Nazionale d' Abruzzo, Lazio e Molise & http://www.parcoabruzzo.it/ (accessed on 15-8-2020) \\
\hline A2 & Parco Nazionale dell'Alta Murgia & $\begin{array}{l}\text { https://www.parcoaltamurgia.gov.it/ (accessed on } \\
\text { 15-8-2020) }\end{array}$ \\
\hline A3 & $\begin{array}{c}\text { Parco Nazionale dell'appennino Lucano-Val } \\
\text { d'Agri-Lagonegrese }\end{array}$ & $\begin{array}{l}\text { http:/ / www.parcoappenninolucano.it/enteparco } \\
\text { (accessed on 15-8-2020) }\end{array}$ \\
\hline A4 & Parco Nazionale dell' Appennino Tosco-Emiliano & http:/ / www.parcoappennino.it/ (accessed on 15-8-2020) \\
\hline A5 & Parco Nazionale dell'Arcipelago di La Maddalena & http://www.lamaddalenapark.it/ (accessed on 15-8-2020) \\
\hline A6 & Parco Nazionale dell'Arcipelago Toscano & http://www.islepark.it/ (accessed on 15-8-2020) \\
\hline A7 & Parco Nazionale dell'Asinara & http:/ / www.parcoasinara.org/ (accessed on 15-8-2020) \\
\hline A8 & Parco Nazionale dell'Aspromonte & $\begin{array}{l}\text { http:/ / www.parcoaspromonte.gov.it/ (accessed on } \\
15-8-2020)\end{array}$ \\
\hline A9 & Parco Nazionale del Cilento, Vallo di Diano e Alburni & http://www.cilentoediano.it/ (accessed on 15-8-2020) \\
\hline A10 & Parco Nazionale delle Cinque Terre & $\begin{array}{l}\text { http:/ / www.parconazionale5terre.it/ (accessed on } \\
\text { 15-8-2020) }\end{array}$ \\
\hline A11 & Parco Nazionale del Circeo & http:/ / www.parcocirceo.it/ (accessed on 15-8-2020) \\
\hline A12 & Parco Nazionale delle Dolomiti Bellunesi & http://www.dolomitipark.it/ (accessed on 15-8-2020) \\
\hline A13 & $\begin{array}{c}\text { Parco Nazionale delle Foreste Casentinesi, Monte } \\
\text { Falterona e Campigna }\end{array}$ & $\begin{array}{l}\text { https://www.parcoforestecasentinesi.it/ (accessed on } \\
\text { 15-8-2020) }\end{array}$ \\
\hline A14 & Parco Nazionale del Gargano & $\begin{array}{l}\text { https:/ / www.parcogargano.it/servizi/notizie/notizie_ } \\
\text { homepage.aspx (accessed on 15-8-2020) }\end{array}$ \\
\hline A15 & Parco Nazionale del Gran Paradiso & http://www.pngp.it/ (accessed on 15-8-2020) \\
\hline A16 & Parco Nazionale del Gran Sasso e Monti della Laga & http:/ /www.gransassolagapark.it/ (accessed on 15-8-2020) \\
\hline A17 & Parco Nazionale della Majella & https:/ / www.parcomajella.it/ (accessed on 15-8-2020) \\
\hline A18 & Parco Nazionale dei Monti Sibillini & http:/ /www.sibillini.net/ (accessed on 15-8-2020) \\
\hline A19 & Parco Nazionale del Pollino & http://www.parcopollino.it/ (accessed on 15-8-2020) \\
\hline A20 & Parco Nazionale della Sila & http://www.parcosila.it/it/ (accessed on 15-8-2020) \\
\hline A 21 & Parco Nazionale dello Stelvio & http:/ / www.stelviopark.it/ (accessed on 15-8-2020) \\
\hline A22 & Parco Nazionale della Val Grande & http:/ /www.parcovalgrande.it/ (accessed on 15-8-2020) \\
\hline A23 & Parco Nazionale del Vesuvio & $\begin{array}{l}\text { https://www.parconazionaledelvesuvio.it/ (accessed on } \\
\text { 15-8-2020) }\end{array}$ \\
\hline
\end{tabular}

In order to calculate the values of the weights of the criteria, Kabassi \& Martinis [14] used AHP. That particular model was selected because it has a very well-defined method for calculating the weights of the criteria, unlike many other decision-making models such as SAW, etc. The weights of the criteria estimated by Kabassi \& Martinis [14] are presented in Table 2. 
Table 2. The website criteria.

\begin{tabular}{ll}
\hline Criterion & Weight \\
\hline Quality of content & $w_{1}=0.274$ \\
Attractiveness & $w_{2}=0.181$ \\
Navigability & $w_{3}=0.114$ \\
Relevancy & $w_{4}=0.109$ \\
Accessibility & $w_{5}=0.083$ \\
Responsiveness & $w_{6}=0.058$ \\
Links & $w_{7}=0.055$ \\
Multilingualism & $w_{8}=0.046$ \\
Quality of mobile interactiveness & $w_{9}=0.046$ \\
Services & $w_{10}=0.034$ \\
\hline
\end{tabular}

\subsection{Application of PROMETHEE II}

The main steps of the outranking method PROMETHEE II after having defined the criteria and their weights of importance are:

Forming a set of evaluators. In this phase of the evaluation, an inspection method is used and, therefore, the group of evaluators is comprised only of expert users. More specifically, eight users participated in the experiment. Some of these particular users were environmentalists and other software engineers that had experience with environmental websites.

Calculating the values of the criteria. In this step, the evaluators selected in step 1 are asked to visit the websites of the NPs of Italy that are presented in Section 2, and to provide values to the 10 criteria of the evaluation (Section 3). Those values must be taken from a nine-number scale to ensure that the values will be comparable. As soon as all the values of the eight decision-makers are collected, the geometric mean for the corresponding values of each criterion for each website is calculated. The results are shown in Table 3.

Table 3. The geometric mean of the values of the criteria for all websites.

\begin{tabular}{|c|c|c|c|c|c|c|c|c|c|c|c|}
\hline & & c1 & c2 & c3 & c4 & c5 & c6 & c7 & c8 & c9 & c10 \\
\hline A1 & $\begin{array}{l}\text { Parco Nazionale } \\
\text { d'Abruzzo, Lazio } \\
\text { e Molise }\end{array}$ & 23 & 30 & 43 & 42 & 43 & 43 & 29 & 48 & 29 & 21 \\
\hline A2 & $\begin{array}{c}\text { Parco Nazionale dell' } \\
\text { Alta Murgia }\end{array}$ & 22 & 22 & 37 & 39 & 43 & 43 & 31 & 58 & 37 & 21 \\
\hline A3 & $\begin{array}{l}\text { Parco Nazionale dell' } \\
\text { apennino Lucano-Va } \\
\text { d'Agri-Lagonegrese }\end{array}$ & 26 & 26 & 31 & 28 & 36 & 37 & 23 & 14 & 29 & 36 \\
\hline $\mathrm{A} 4$ & $\begin{array}{l}\text { Parco Nazionale } \\
\text { dell'Appennino } \\
\text { Tosco-Emiliano }\end{array}$ & 31 & 23 & 29 & 29 & 43 & 41 & 36 & 34 & 36 & 21 \\
\hline A5 & $\begin{array}{c}\text { Parco Nazionale } \\
\text { dell'Arcipelago di La } \\
\text { Maddalena }\end{array}$ & 26 & 27 & 31 & 31 & 43 & 37 & 29 & 50 & 36 & 29 \\
\hline A6 & $\begin{array}{c}\text { Parco Nazionale } \\
\text { dell'Arcipelago Toscano }\end{array}$ & 31 & 30 & 23 & 18 & 43 & 29 & 51 & 7 & 36 & 7 \\
\hline
\end{tabular}


Table 3. Cont.

\begin{tabular}{|c|c|c|c|c|c|c|c|c|c|c|c|}
\hline & & c1 & c2 & c3 & c4 & c5 & c6 & c7 & c8 & c9 & c10 \\
\hline A7 & $\begin{array}{l}\text { Parco Nazionale } \\
\text { dell'Asinara }\end{array}$ & 36 & 28 & 28 & 29 & 44 & 29 & 36 & 7 & 36 & 36 \\
\hline A8 & $\begin{array}{l}\text { Parco Nazionale } \\
\text { dell'Aspromonte }\end{array}$ & 44 & 28 & 28 & 29 & 43 & 35 & 29 & 14 & 36 & 29 \\
\hline A9 & $\begin{array}{c}\text { arco Nazionale del } \\
\text { Cilento, Vallo di Diano } \\
\text { e Alburni }\end{array}$ & 44 & 42 & 36 & 45 & 43 & 49 & 50 & 20 & 50 & 43 \\
\hline A10 & $\begin{array}{l}\text { Parco Nazionale delle } \\
\text { Cinque Terre }\end{array}$ & 51 & 43 & 36 & 43 & 43 & 36 & 43 & 39 & 50 & 36 \\
\hline A11 & $\begin{array}{c}\text { Parco Nazionale } \\
\text { del Circeo }\end{array}$ & 37 & 23 & 37 & 43 & 29 & 36 & 36 & 39 & 43 & 29 \\
\hline A12 & $\begin{array}{l}\text { Parco Nazionale delle } \\
\text { Dolomiti Bellunesi }\end{array}$ & 43 & 29 & 35 & 42 & 36 & 41 & 36 & 63 & 50 & 36 \\
\hline A13 & $\begin{array}{l}\text { Parco Nazionale delle } \\
\text { Foreste Casentinesi, } \\
\text { Monte Falterona } \\
\text { e Campigna }\end{array}$ & 30 & 43 & 37 & 36 & 43 & 43 & 29 & 28 & 50 & 36 \\
\hline A14 & $\begin{array}{l}\text { Parco Nazionale } \\
\text { del Gargano }\end{array}$ & 37 & 43 & 30 & 43 & 44 & 50 & 36 & 27 & 50 & 21 \\
\hline A15 & $\begin{array}{l}\text { Parco Nazionale del } \\
\text { Gran Paradiso }\end{array}$ & 44 & 37 & 43 & 36 & 43 & 50 & 43 & 23 & 50 & 21 \\
\hline A16 & $\begin{array}{l}\text { Parco Nazionale del Gran } \\
\text { Sasso e Monti della Laga }\end{array}$ & 36 & 43 & 43 & 30 & 43 & 50 & 36 & 42 & 50 & 21 \\
\hline A17 & $\begin{array}{l}\text { Parco Nazionale } \\
\text { della Majella }\end{array}$ & 52 & 51 & 52 & 44 & 49 & 48 & 50 & 36 & 57 & 29 \\
\hline A18 & $\begin{array}{l}\text { Parco Nazionale dei } \\
\text { Monti Sibillini }\end{array}$ & 28 & 29 & 35 & 36 & 48 & 36 & 29 & 15 & 15 & 14 \\
\hline A19 & $\begin{array}{l}\text { Parco Nazionale } \\
\text { del Pollino }\end{array}$ & 35 & 35 & 29 & 36 & 58 & 42 & 36 & 20 & 22 & 29 \\
\hline A20 & $\begin{array}{l}\text { Parco Nazionale } \\
\text { della Sila }\end{array}$ & 30 & 36 & 30 & 30 & 43 & 43 & 29 & 14 & 36 & 29 \\
\hline A21 & $\begin{array}{l}\text { Parco Nazionale } \\
\text { dello Stelvio }\end{array}$ & 36 & 36 & 50 & 43 & 43 & 42 & 36 & 33 & 36 & 43 \\
\hline A22 & $\begin{array}{c}\text { Parco Nazionale dela } \\
\text { Val Grande }\end{array}$ & 38 & 50 & 37 & 37 & 43 & 50 & 36 & 48 & 50 & 43 \\
\hline A23 & $\begin{array}{l}\text { Parco Nazionale } \\
\text { del Vesuvio }\end{array}$ & 37 & 42 & 43 & 36 & 42 & 37 & 42 & 33 & 43 & 43 \\
\hline
\end{tabular}

Calculating the preference degree. For each pair of websites and for each one of the 10 criteria, the value of the preference degree is calculated. Let $g_{j}(a)$ be the value of a criterion $j$ for a website a. We note $d_{j}(a, b)$, the difference of the value of a criterion $j$ for two websites $a$ and $b$.

$$
d_{j}(a, b)=g_{j}(a)-g_{j}(b)
$$

$P_{j}(a, b)$ is the value of the preference degree of a criterion $j$ for two websites $a$ and $b$. The preference functions used to compute these preference degrees are defined such as:

$$
\begin{gathered}
P_{j}(a, b)=0, \text { if } d_{j}(a, b)<0 \\
P_{j}(a, b)=d_{j}(a, b), \text { if } d_{j}(a, b)>0
\end{gathered}
$$


Aggregating the preference degrees. For each pair of possible websites, we compute a global preference index as follows:

$$
\pi(a, b)=\left[\sum_{j=1}^{n} w_{j} P_{j}(a, b)\right] / \sum_{j=1}^{n} w_{j},
$$

$w_{j}$ is the weight associated to criterion $j$

Calculate positive and negative outranking flow. For each website $a$, we compute the positive outranking flow $\phi^{+}(\alpha)$ by the following formulae:

$$
\begin{aligned}
\phi^{+}(\alpha) & =\frac{1}{m-1} \sum_{b=1}^{m} \pi(\alpha, b) \text { when } \alpha \neq b \\
\phi^{-}(\alpha) & =\frac{1}{m-1} \sum_{b=1}^{m} \pi(b, a) \text { when } \alpha \neq b
\end{aligned}
$$

Calculate the net outranking flow. The outranking flow $\phi(\alpha)$ is calculated for each alternative website as follows: $\phi(\alpha)=\phi^{+}(\alpha)-\phi^{-}(\alpha)$. The results for all the websites are presented in Figure 2 and Table 4.

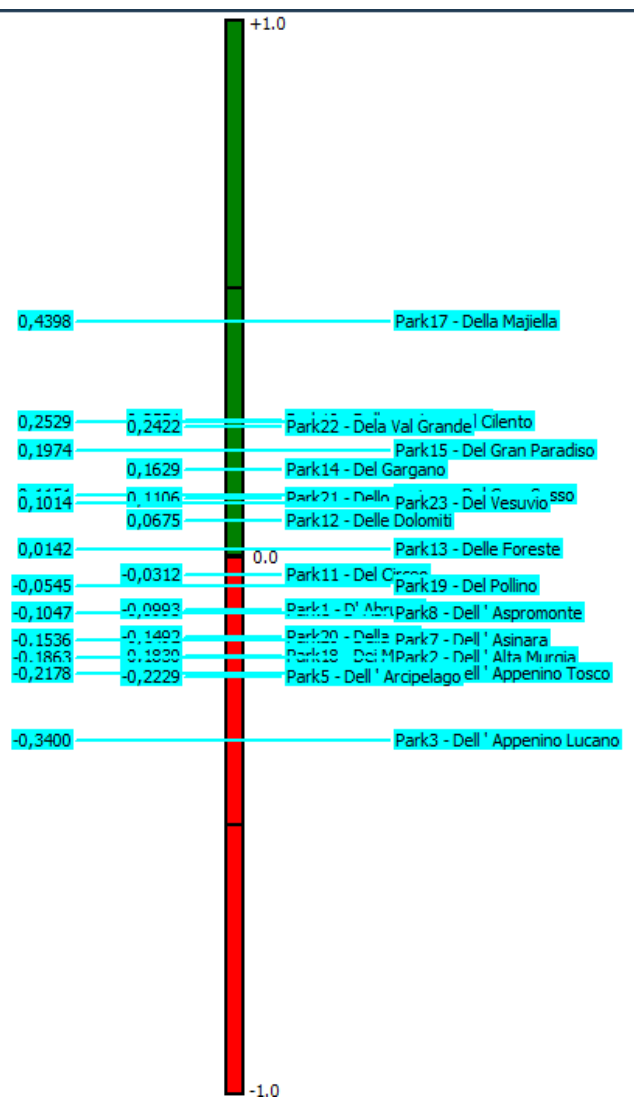

Figure 2. Graphic depiction of the quality of websites. 
Table 4. Values and Ranking for all websites using SAW, WPM, TOPSIS and PROMETHEE II.

\begin{tabular}{|c|c|c|c|c|c|c|c|c|}
\hline & SAW & SAW Ranking & WPM & WPM Ranking & PROMETHEE II & $\begin{array}{l}\text { PROMETHEE } \\
\text { II Ranking }\end{array}$ & TOPSIS & TOPSIS Ranking \\
\hline A1 & 32.8199 & 15 & 31.584 & 15 & -0.099 & 14 & 0.297 & 15 \\
\hline A2 & 31.362 & 18 & 29.886 & 20 & -0.186 & 19 & 0.256 & 18 \\
\hline A3 & 27.566 & 23 & 27.078 & 22 & -0.340 & 23 & 0.151 & 23 \\
\hline A4 & 30.727 & 20 & 30.185 & 17 & -0.218 & 21 & 0.215 & 21 \\
\hline A5 & 30.727 & 19 & 30.132 & 18 & -0.223 & 22 & 0.220 & 20 \\
\hline A6 & 28.477 & 22 & 26.150 & 23 & -0.217 & 20 & 0.210 & 22 \\
\hline A7 & 31.418 & 17 & 30.049 & 19 & -0.154 & 17 & 0.259 & 17 \\
\hline A8 & 33.594 & 14 & 32.464 & 14 & -0.105 & 15 & 0.320 & 13 \\
\hline A9 & 42.289 & 3 & 41.710 & 3 & 0.253 & 3 & 0.429 & 4 \\
\hline A10 & 43.595 & 2 & 43.244 & 2 & 0.255 & 2 & 0.445 & 3 \\
\hline A11 & 34.052 & 13 & 33.336 & 13 & -0.031 & 12 & 0.300 & 14 \\
\hline A12 & 39.059 & 8 & 38.331 & 8 & 0.068 & 10 & 0.369 & 10 \\
\hline A13 & 36.245 & 11 & 35.677 & 11 & 0.014 & 11 & 0.369 & 11 \\
\hline A14 & 38.512 & 10 & 37.823 & 10 & 0.163 & 6 & 0.392 & 9 \\
\hline A15 & 40.255 & 5 & 39.583 & 5 & 0.197 & 5 & 0.403 & 7 \\
\hline A16 & 38.915 & 9 & 38.322 & 9 & 0.115 & 7 & 0.407 & 5 \\
\hline A17 & 48.854 & 1 & 48.451 & 1 & 0.44 & 1 & 0.514 & 1 \\
\hline A18 & 30.004 & 21 & 28.788 & 21 & -0.183 & 18 & 0.229 & 19 \\
\hline A19 & 34.994 & 12 & 34.061 & 12 & -0.055 & 13 & 0.324 & 12 \\
\hline A20 & 31.974 & 16 & 31.293 & 16 & -0.149 & 16 & 0.263 & 16 \\
\hline A21 & 39.091 & 7 & 38.786 & 7 & 0.111 & 8 & 0.394 & 8 \\
\hline A22 & 41.866 & 4 & 41.490 & 4 & 0.242 & 4 & 0.461 & 2 \\
\hline A23 & 39.148 & 6 & 39.017 & 6 & 0.102 & 9 & 0.404 & 6 \\
\hline
\end{tabular}

\section{Results}

\subsection{Ranking Websites with PROMETHEE II}

The application of PROMETHEE II assigned a value $\phi(\alpha)$ to each website. The $\phi(\alpha)$ values of all alternative values are presented in Table 4 . The higher the value of $\phi(\alpha)$ is for an environmental website, the higher the ranking is of that website.

All websites of the NPs contained general information about the NP, such as information about its structure, objectives, financial statements, etc. Additionally, all of them contained information about the ecosystem of the PA and gave contact information. This also confirms the results of another study for the NPs of Greece [14].

A graphic depiction of the quality of the websites is presented in Figure 2, taking into account the values $\phi(\alpha)$. According to Figure 2 and Table 4, almost half of the websites are considered good. The best one is the website of Della Majiella (A17). The value of $\phi(\alpha)$ for A17 is much higher than the value of $\phi(\alpha)$ all the other websites. The websites of the NPs that have a value $\phi(\alpha)$ that is lower than zero are not considered very good at promoting environmental information and need a redesign and update of content.

\subsection{Comparison with Other MCDM}

In order to check whether PROMETHEE II is effective in ranking environmental websites, a comparison with three other common MCDM models was conducted. More specifically, SAW, WPM and TOPSIS, were selected for this purpose. These three models are very popular and have been implemented in the past for the evaluation of websites and have proved to be rather effective $[9,16,22]$. 
For this purpose, we use the values of criteria given by all users that are presented in Table 3. According to SAW, we calculate the multi-attribute utility function $U$ for each one of the 23 websites as a linear combination of the values of the 10 criteria:

$$
U\left(A_{j}\right)=\sum_{i=1}^{10} w_{i} x_{i j}
$$

where $A_{j}$ is one alternative website and $x_{i j}$ is the value of the $i$ criterion for the $A_{j}$ website.

Similarly, according to WPM the utility function $U$ is calculated for each one of the same websites.

$$
U\left(A_{j}\right)=\prod_{i=1}^{10}\left(u x_{i j}\right)^{w_{i}}
$$

for $j=1, \ldots, 23$.

The term $U\left(A_{j}\right)$ denoted the total performance value of the alternative $A_{j}$.

The central principle in TOPSIS model is that the best alternative should have the shortest distance from the ideal solution and the farthest distance from the negative-ideal solution.

Identify Positive-Ideal and Negative-Ideal Solutions. The positive ideal solution is the composite of all best attribute ratings attainable and is denoted:

$$
A^{*}=\left\{v_{1}^{*}, v_{2}^{*}, v_{3}^{*}\right\}
$$

where $v_{i}^{*}$ is the best-weighted rating for the dimension $i$ among all alternatives. The negative-ideal solution is the composite of all worst attribute ratings attainable, and is denoted:

$$
A^{-}=\left\{v_{1}^{-}, v_{2}^{-}, v_{3}^{-}\right\}
$$

where $v_{i}^{-}$is the worst value for the dimension $i$ among all websites.

Calculate the separation measure from the positive-ideal and negative-ideal alternative. The separation of each alternative from the positive-ideal solution $A^{*}$ is given by the $n$-dimensional Euclidean distance:

$$
S_{j}^{*}=\sqrt{\sum_{i=1}^{3}\left(v_{i j}-v_{i}^{*}\right)^{2}},
$$

where $j$ is the index related to the alternatives and $i$ one of the $n$ attributes. Similarly, the separation from the negative-ideal solution $A^{-}$is given by

$$
S_{j}^{-}=\sqrt{\sum_{i=1}^{10}\left(v_{i j}-v_{i}^{-}\right)^{2}} .
$$

Calculate Similarity Indexes. The similarity to positive-ideal solution, for alternative $j$, is finally given by

$$
C_{j}^{*}=\frac{S_{j}^{-}}{S_{j}^{*}+S_{j}^{-}}
$$

with $0 \leq C_{j}^{*} \leq 1$. The alternatives can then be ranked according to $C_{j}^{*}$ in descending order.

The values of utility function $U$ using SAW, WPM, C of TOPSIS, and the final value $\phi(\alpha)$ of PROMETHEE II for each alternative website are used for ranking the 23 websites. The higher the value of $U, \mathrm{C}$ or $\phi(\alpha)$, the better the website is considered. The values of $U$ according to SAW and WPM, the values of C according to TOPSIS and the values of $\phi(\alpha)$ according to PROMETHEE II as well as the ranking order to the websites using the four different models are presented in Table 4. 


\subsection{Sensitivity Analysis}

In order to evaluate the consistency of the results of PROMETHEE II, a sensitivity analysis was performed. The main aim of a sensitivity analysis is to evaluate how the MCDM models change the ranking of the alternatives when input data are slightly modified [44]. For this purpose, we used a second scheme of weights which assigned equal weight to each of the criteria $[45,46]$. Since there are 10 criteria, the weight for each criterion was determined to be 0.1 . The values of the utility function $U$ using SAW or WPM, the values of $\mathrm{C}$ using TOPSIS and the values of $\phi(\alpha)$ for each website were recalculated using the second weighting scheme. All these new values of $\mathrm{U}, \mathrm{C}$ and $\phi(\alpha)$, as well as the new raking orders of the websites using each one of the three MCDM models, are presented in Table 5.

Table 5. Values and Ranking order for all websites using SAW, WPM, and PROMETHEE II using equal weights of criteria.

\begin{tabular}{|c|c|c|c|c|c|c|c|c|}
\hline & SAW & SAW Ranking & WPM & WPM Ranking & PROMETHEE II & $\begin{array}{l}\text { PROMETHEE } \\
\text { II Ranking }\end{array}$ & TOPSIS & TOPSIS Ranking \\
\hline A1 & 34.875 & 13 & 33.584 & 13 & -0.123 & 14 & 0.529 & 13 \\
\hline A2 & 35.213 & 12 & 33.549 & 14 & -0.168 & 15 & 0.561 & 9 \\
\hline A3 & 28.2 & 22 & 27.311 & 21 & -0.572 & 23 & 0.319 & 21 \\
\hline A4 & 32.063 & 17 & 31.361 & 17 & -0.399 & 21 & 0.421 & 17 \\
\hline A5 & 33.488 & 16 & 32.752 & 15 & -0.323 & 18 & 0.511 & 14 \\
\hline A6 & 27.288 & 23 & 22.991 & 23 & -0.522 & 22 & 0.312 & 22 \\
\hline A7 & 30.5625 & 20 & 28.131 & 20 & -0.296 & 17 & 0.365 & 19 \\
\hline A8 & 31.15 & 19 & 29.923 & 19 & -0.371 & 19 & 0.360 & 20 \\
\hline A9 & 42.025 & 3 & 40.916 & 4 & 0.501 & 2 & 0.585 & 7 \\
\hline A10 & 41.713 & 4 & 41.394 & 3 & 0.360 & 4 & 0.611 & 4 \\
\hline A11 & 34.825 & 14 & 34.222 & 12 & -0.100 & 12 & 0.498 & 15 \\
\hline A12 & 40.825 & 5 & 39.896 & 5 & 0.117 & 11 & 0.640 & 3 \\
\hline A13 & 37.15 & 11 & 36.492 & 11 & 0.145 & 10 & 0.551 & 10 \\
\hline A14 & 37.85 & 10 & 36.610 & 10 & 0.294 & 6 & 0.533 & 11 \\
\hline A15 & 38.863 & 9 & 37.520 & 9 & 0.295 & 5 & 0.532 & 12 \\
\hline A16 & 39.163 & 8 & 38.109 & 8 & 0.220 & 8 & 0.604 & 5 \\
\hline A17 & 46.525 & 1 & 45.704 & 1 & 0.768 & 1 & 0.668 & 2 \\
\hline A18 & 28.25 & 21 & 26.155 & 22 & -0.392 & 20 & 0.291 & 23 \\
\hline A19 & 33.938 & 15 & 32.507 & 16 & -0.111 & 13 & 0.427 & 16 \\
\hline A20 & 31.663 & 18 & 30.494 & 18 & -0.245 & 16 & 0.380 & 18 \\
\hline A21 & 39.513 & 6 & 39.201 & 7 & 0.255 & 7 & 0.585 & 8 \\
\hline A22 & 42.95 & 2 & 42.567 & 2 & 0.499 & 3 & 0.694 & 1 \\
\hline A23 & 39.488 & 7 & 39.322 & 6 & 0.167 & 9 & 0.597 & 6 \\
\hline
\end{tabular}

In order to compare the consistency of the MCDM models, we evaluated the robustness of the ranking produced by each model based on the results of the sensitivity analysis. The consistency of an MCDM model is low if the ranking of the alternatives is severely modified when the weights differentiate. Therefore, we compare the rankings produced by the same model using the different schemes of weights. In order to compare how close the rankings of each model are using the two schemes of weights, we use Spearman's Rho correlation test to analyze the correlation among the obtained rankings.

The Spearman's Rho correlation is estimated by:

$$
R=1-\frac{6 \sum_{i=1}^{n} d_{i}^{2}}{n\left(n^{2}-1\right)}
$$

where $d_{i}$ is the rank different at position $i$ and $n$ is the number of ranks. 
The values of Spearman's Rho for the pair-wise comparisons of MCDM models are: Rsaw $=0.929$, Rwpm $=0.936$, Rpromethee $=0.967$, Rtopsis $=0.841$. The Spearman's Rho has its highest value for PROMETHEE II and, therefore, PROMETHEE II has the higher consistency the results when compared with SAW, WPM and TOPSIS. This means that it is less affected by changes in the values or in the weights of the criteria. Consistency is considered to be important when selecting an MCDM model. Since PROMETHEE II is less affected by the subjectivity of the reasoning of the decision-makers, it proved to be better than the other three models.

\section{Discussion}

The evaluation of the environmental websites, especially the evaluation of websites of NPs, is very important to confirm that they meet their goals and manage to promote environmental education. Moreover, good websites and good social media exposure are important factors stimulating tourism development in NPs, which raises the awareness of the PA and the whole region [5]. Environmental websites have been evaluated before using MCDM models [9,14]. Table 6 shows the different evaluation experiments that involve websites of NPs, the countries that they involve, the MCDM models that are used if they present a comparison between MCDM models, and whether they have undergone a sensitivity analysis.

Table 6. Evaluation experiments of the websites of national parks.

\begin{tabular}{ccccc}
\hline Evaluation Experiment & Country & MCDM Model & Comparison with Other Models & Sensitivity Analysis \\
\hline Martinis et al. 2018 & Greece & - & - & - \\
\hline Kabassi et al. 2019 & Greece & AHP & - & - \\
\hline Kabassi \& Martinis 2020 & Greece & AHP \& VIKOR & - & - \\
\hline Kabassi et al. 2021 & Greece \& Italy & $\begin{array}{c}\text { AHP \& } \\
\text { PROMETHEE II }\end{array}$ & SAW & - \\
\hline Current study & Italy & $\begin{array}{c}\text { AHP \& } \\
\text { PROMETHEE II }\end{array}$ & SAW \& WPM \& TOPSIS & $\sqrt{ }$ \\
\hline
\end{tabular}

The websites of NPs in Greece have been evaluated by Martinis et al. [16], Kabassi et al. [9], and Kabassi \& Martinis [14]. The websites of NPs in both Greece and Italy have been evaluated in Kabassi et al. [22]. In that paper, conclusions have been drawn by comparing the electronic presence of NPs in two neighboring countries using a combination of AHP \& PROMETHEE II. A more thorough study on the NPs in Italy is implemented in the current experiment. Furthermore, PROMETHEE II is compared with SAW, WPM and TOPSIS as far as their combination with AHP is concerned. However, the main difference between the current study and the previous studies except for the country of the NPs is concerning the comparison of PROMETHEE II with SAW, WPM or TOPSIS, and the sensitivity analysis that is performed. Previously, PROMETHEE II has only been combined with SAW, and this comparison did not involve the implementation of a sensitivity analysis. Therefore, the comparison was not thorough and did not involve evaluation or comparison of the robustness of the models used.

The comparison of a model with other available models is rather important because different methods can produce different results while being applied to an identical problem. As a result, researchers in the field $[47,48]$ consider it important to examine the compatibility of different multi-criteria decision-making methods with a particular type of decision problem. The comparison of MCDM models has been proved essential in order to decide whether the model used in each purpose is the most appropriate. Therefore, different studies have applied different MCDM models to the same problem and compared the obtained rankings [19,21,25,49-58]. 
PROMETHEE II has been compared with TOPSIS, VIKOR, AHP, Entropy, and ELECTRE $[48,59-61]$ in different domains. Regarding the comparison of PROMETHEE II with the TOPSIS, SAW, and WPM models described in this paper, a comparison of PROMETHEE II with SAW was implemented before [21] by Widianta et al. [62] for making decisions for employee placement. PROMETHEE II has also been compared with both SAW and WPM for evaluating different energy scenarios [63]. Similarly, PROMETHEE II has been compared with TOPSIS in several domains [64] e.g., for the evaluation of tool holders in hard milling [60] and for pipe material selection in the sugar industry [59]. PROMETHEE II has been compared before with SAW with regard to environmental websites, but the comparison did not involve a sensitivity analysis and, therefore, an evaluation of the robustness of the models.

The sensitivity analysis is not only performed for PROMETHEE II but for the other MCDM that take part in the comparison, these being SAW, WPM and TOPSIS. Sensitivity analyses of different MCDM models have also been implemented in different domains $[45,46,65,66]$. As a result, such an analysis has been performed for PROMETHEE II [50], TOPSIS [65-67], SAW [66,68,69], and WPM [30]. Although sensitivity analysis of the models has been implemented before in different domains, this is the first time that it has been implemented for estimating the consistency of the MCDM models in environmental website evaluation.

\section{Conclusions}

In this paper, we use MCDM models for combining the criteria that are involved in the evaluation of the content of environmental websites. MCDM models such as VIKOR, have been applied in the past for combining evidence of the evaluation of environmental websites [14]. In this paper, we presented how PROMETHEE II can be combined effectively with other MCDM models for website evaluation, and we then ran a sensitivity analysis.

PROMETHEE II is recent outranking method that proved to be effective for ranking alternatives. The theory performs the ranking of alternatives while considering several conflicting criteria [70]. Its advantage is that it is easy to use. It does not require the assumption that the criteria are proportionate. The disadvantages are that it does not provide a clear method by which to assign weights and it requires the assignment of values [21]. For this reason, we combined PROMETHEE II with AHP.

Taking into account the results of the evaluation of the websites, PROMETHEE II proved to be both easy to implement and effective. However, in order to see whether the ranking provided by PROMETHEE II was correct and resembled other MCDM models, we conducted a comparative analysis.

The main contribution of the paper is on comparing PROMETHEE II with three other common MCDM models. As a result, conclusions that involve the appropriateness of PROMETHEE II for the ranking of environmental websites as well as the robustness of the different MCDM models were discussed in the current paper.

The comparison of PROMETHEE II with other methods such as SAW, WPM, and TOPSIS provided evidence for the effectiveness of PROMETHEE II. As Velasquez \& Hester [21] point out, many researchers use TOPSIS to confirm the answers proposed by other MCDM methods. In our study, the three MCDM models that are compared with PROMETHEE II confirmed that PROMETHEE II is effective in providing a good ranking.

In order to see if PROMETHEE II was better than the other MCDM models, we proceeded to a sensitivity analysis. This kind of analysis sought to determine how the modifications of independent variables, such as criteria values or their weights, affected the outcome of the model. A particular analysis was performed to check the influence of the weighting of the criteria in the final ranking.

The sensitivity analysis proved that PROMETHEE II is more robust than SAW, WPM and TOPSIS and less affected by changes in weights or values of the criteria. The results were more consistent throughout the different weighting schemes. PROMETHEE II provides a good ranking of the alternative environmental websites and is less affected by 
the subjectivity of expert users compared to the other MCDM models. Consequently, PROMETHEE II is preferred for the evaluation of environmental websites over SAW, WPM or TOPSIS.

The results of the PROMETHEE II model as well as the other three models revealed that the electronic presence of NPs is mediocre. Findings are in agreement with those of similar studies $[2,14,16,22]$ and confirm that internet technologies' adoption in NPs is still at an initial level.

A research limitation of the study was the sample of the decision makers. Although the decisionmakers are experts and the evaluation experiment is an inspection evaluation, an empirical evaluation with the participation of many real potential users may have provided better results and more conclusions regarding the electronic presence of NPs in Italy. Furthermore, the sensitivity analysis could include more weighting schemes and, therefore, provide more conclusions regarding the consistency of the methods. Taking into account the limitations of the current study, we intend to implement an empirical evaluation with the participation of many real potential users and not just experts. Furthermore, a comparative study with more MCDM models could be implemented. The comparative analysis could reveal if the selection of the MCDM model may differentiate the ranking results or not. Finally, a more extensive sensitivity analysis could be implemented with the use of many different weighting schemes for the criteria.

Author Contributions: Conceptualization, K.K. and A.M.; methodology, K.K. and A.M.; validation, K.K.; formal analysis, K.K.; investigation, A.M.; data curation, A.M.; writing-original draft preparation, K.K. and A.M.; writing-review and editing, K.K.; project administration, A.M.; funding acquisition, A.M. All authors have read and agreed to the published version of the manuscript.

Funding: This research received no external funding.

Institutional Review Board Statement: Not applicable.

Informed Consent Statement: Not applicable.

Data Availability Statement: Not applicable.

Conflicts of Interest: The authors declare no conflict of interest.

\section{References}

1. Rusielik, R.; Zbaraszewski, W. The efficiency of scientific and tourism activity of Polish National Parks with use DEA method. Econ. Environ. Stud. 2014, 14, 283.

2. Andreopoulou, Z.; Koliouska, C.H.; Lemonakis, C.H.; Zopounidis, C. National Forest Parks development through Internet technologies for economic perspectives. Oper. Res. 2015, 15, 395-421. [CrossRef]

3. Ho, C.I.; Chou-Yen, H.T. An empirical study on the effectiveness of computer-mediated tour information. J. Outdoor Recreat. Study 2003, 16, 25-43. (In Chinese)

4. Głabiński, Z. Ecological awareness of tourists in the coastal areas of Poland-Preliminary results of the survey. In Bulletin of Geography. Socio-Economic Series, No. 28; Szymańska, D., Chodkowska-Miszczuk, J., Eds.; Nicolaus Copernicus University: Toruń, Poland, 2015; pp. 53-68. [CrossRef]

5. Qin, X.; Huang, G.; Chakma, A.; Nie, X.; Lin, Q. A MCDM-based expert system for climate-change impact assessment and adaptation planning-A case study for the Georgia Basin, Canada. Expert Syst. Appl. 2008, 34, 2164-2179. [CrossRef]

6. Saaty, T.L. The Analytic Hierarchy Process; McGraw-Hill: New York, NY, USA, 1980.

7. Thapa, B.; Lee, J. Visitor experience in Kafue National Park, Zambia. J. Ecotourism 2017, 16, 112-130. [CrossRef]

8. Tomaskinova, J.; Tomaskin, J.; Soporska, P. Ecosystem services and recreational values as building blocks for eco development in NATURA 2000 sites. Pol. J. Environ. Stud. 2019, 28, 1925-1932. [CrossRef]

9. Kabassi, K.; Martinis, A.; Papadatou, A. Analytic Hierarchy Process in an Inspection Evaluation of National Parks' Websites: The Case Study of Greece. J. Environ. Manag. Tour. 2019, 37, 956-966. [CrossRef]

10. Fotakis, T.; Economides, A.A. Art, science/technology and history museums on the web. Int. J. Digit. Cult. Electron. Tour. 2008, 1, 37-63. [CrossRef]

11. Pamučar, D.S.; Božanić, D.; Ranđelović, A. Multi-Criteria Decision Making: An example of sensitivity analysis. Serb. J. Manag. 2017, 12, 1-27. [CrossRef]

12. Kabassi, K.; Botonis, A.; Karydis, C. Evaluating Websites of Specialised Cultural Content using Fuzzy Multi-Criteria Decision Making Theories. Informatica 2020, 44, 45-54. [CrossRef] 
13. Kabassi, K.; Karydis, C.; Botonis, A. AHP, Fuzzy SAW and Fuzzy WPM for the evaluation of Cultural Websites. Multimodal Technol. Interact. 2020, 4, 5. [CrossRef]

14. Kabassi, K.; Martinis, A. Evaluating the Electronic Presence of Protected Areas Managing Boards in Greece using a Combination of Different Methods and Theories. J. Ecotourism 2020, 19, 50-72. [CrossRef]

15. Kabassi, K.; Amelio, A.; Komianos, V.; Oikonomou, K. Evaluating Museum Virtual Tours: The case study of Italy. Information 2019, 10, 351. [CrossRef]

16. Martinis, A.; Papadatou, A.; Kabassi, K. An Analysis of the Electronic Presence of National Parks in Greece. In Proceedings of the 5th International Conference on "Innovative Approaches to Tourism and Leisure: Culture, Places and Narratives in a Sustainability Context", Athens, Greece, 28-30 June 2018.

17. Saaty, T.; Hu, G. Ranking by Eigenvector Versus Other Methods in the Analytic Hierarchy Process. Appl. Math. Lett. 1998, 11, 121-125. [CrossRef]

18. Sałabun, W.; Watróbski, J.; Shekhovtsov, A. Are MCDA Methods Benchmarkable? A Comparative Study of TOPSIS, VIKOR, COPRAS, and PROMETHEE II Methods. Symmetry 2020, 12, 1549. [CrossRef]

19. Brans, J.P. L'ingenierie de La Decision, L'laboration D'instruments D'aidea La Decision; Colloque sur l'Aidea la Decision; Faculte des Sciences de l'Administration, Universite Laval: Quebec, QC, Canada, 1982; pp. 183-214.

20. Brans, J.P.; Vincke, P. A Preference Ranking Organisation Method, (The PROMETHEE Method for Multiple Criteria DecisionMaking). Manag. Sci. 1985, 31, 647-656. [CrossRef]

21. Widianta, M.M.D.; Rizaldi, T.; Setyohadi, D.P.S.; Riskiawan, H.Y. Comparison of Multi-Criteria Decision Support Methods (AHP, TOPSIS, SAW \& PROMETHEE) for Employee Placement. J. Phys. Conf. Ser. 2018, 953, 012116.

22. Kabassi, K.; Mpalomenou, S.; Martinis, A. AHP \& PROMETHEE II for Evaluation of Websites of Mediterranean Protected Areas' Managing Boards. J. Manag. Inf. Decis. Sci. 2021, 24, 1-17.

23. Goswami, S.S. Outranking Methods: Promethee I and Promethee II. Found. Manag. 2020, 12, 93-110. [CrossRef]

24. Steele, K.; Carmel, Y.; Cross, J.; Wilcox, C. Uses and misuses of multicriteria decision analysis (MCDA) in environmental decision making. Risk Anal. Int. J. 2009, 29, 26-33. [CrossRef]

25. Vassoney, E.; Mammoliti Mochet, A.; Desiderio, E.; Negro, G.; Pilloni, M.G.; Comoglio, C. Comparing Multi-Criteria DecisionMaking Methods for the Assessment of Flow Release Scenarios From Small Hydropower Plants in the Alpine Area. Front. Environ. Sci. 2021, 9. [CrossRef]

26. Alinezhad, A.; Sarrafha, K.; Amini, A. Sensitivity Analysis of SAW Technique: The Impact of Changing the Decision Making Matrix Elements on the Final Ranking of Alternatives. Iran. J. Oper. Res. 2014, 5, 82-94.

27. Hwang, C.L.; Yoon, K. Multiple Attribute Decision Making: Methods and Applications, Lecture Notes in Economics and Mathematical Systems, 1989, 186; Springer: Berlin/Heidelberg, Germany; New York, NY, USA, 1981.

28. Tsai, W.H.; Chou, W.C.; Lai, C.W. An effective evaluation model and improvement analysis for national park websites: A case study of Taiwan. Tour. Manag. 2010, 31, 936-952. [CrossRef]

29. Triantaphyllou, F.; Mann, S.H. An examination of the effectiveness of multi-dimentional decision-making methods: A decision making paradox. Dec. Sup. Sys. 1989, 5, 303-312. [CrossRef]

30. Maiorano, L.; Falcucci, A.; Garton, E.; Boitani, L. Contribution of the Natura 2000 Network to Biodiversity Conservation in Italy. Conserv. Biol. 2007, 21, 1433-1444. [CrossRef]

31. Bastian, O.; Neruda, M.; Filipova, L.; Machova, I.; Leibenath, M. Natura 2000 Sites as an Asset for Rural Development: The German-Czech Ore Mountains Green Network Project. J. Landsc. Ecol. 2012, 3, 41-58. [CrossRef]

32. Triantaphyllou, E. Multi-Criteria Decision Making: A Comparative Study; Kluwer Academic Publishers: Dordrecht, The Netherlands, 2000; ISBN 0-7923-6607-7.

33. Schirpke, U.; Scolozzi, R.; Da Re, R.; Masiero, M.; Pellegrino, D.; Marino, D. Recreational ecosystem services in protected areas: A survey of visitors to Natura 2000 sites in Italy. J. Outdoor Recreat. Tour. 2018, 21, 39-50. [CrossRef]

34. Gantioler, S.; Rayment, M.; Brink, P.T.; Mcconville, A.; Kettunen, M.; Bassi, S. The costs and socio-economic benefits associated with the natura 2000 network. Int. J. Sustain. Soc. 2014, 6, 135-157. [CrossRef]

35. Simanaviciene, R.; Ustinovichius, L. Sensitivity Analysis for Multiple Criteria Decision Making Methods: TOPSIS and SAW. Proc. Soc. Behav. Scienc. 2010, 2, 7743-7744. [CrossRef]

36. Robinson, E.; Albers, H.; Williams, J. Spatial and temporal aspects of nontimber forest product extraction: The role of community resource management. J. Environ. Econ. Manag. 2008, 56, 234-245. [CrossRef]

37. Schagner, J.P.; Brander, L.; Maes, J.; Paracchini, M.L.; Hartje, V. Mapping recreational visits and values of European National Parks by combining statistical modelling and unit value transfer. J. Nat. Conserv. 2016, 31, 71-84. [CrossRef]

38. Yildirim, B.Y.; Önder, E. Evaluating Potential Freight Villages in Istanbul using Multi Criteria Decision Making Techniques. J. Logist. Manag. 2014, 3, 1-10.

39. Robinson, E.; Lokina, R. A spatial-temporal analysis of the impact of access restrictions on forest landscapes and household welfare in Tanzania. For. Policy Econ. 2011, 13, 79-85. [CrossRef]

40. Romano, B.; Zullo, F.; Fiorin, L.; Marucci, A. "The park effect"? An assessment test of the territorial impacts of Italian National Parks, thirty years after the framework legislation. Land Use Policy 2021, 100. [CrossRef]

41. Dudley, N. (Ed.) Guidelines for Applying Protected Area Management Categories; IUCN: Gland, Switzerland, 2008. 
42. Doolin, B.; Burgess, L.; Cooper, J. Evaluating the use of the web for tourism marketing: A case study from New Zealand. Tour. Manag. 2002, 29, 458-468. [CrossRef]

43. Vahid, B.; Zahraie, B.; Roozbahani, A. Comparison of AHP and PROMETHEE Family Decision Making Methods for Selection of Building Structural System. Am. J. Civ. Eng. Archit. 2014, 2, 149-159.

44. Su, M.M.; Wall, G.; Xu, K. Tourism-Induced Livelihood Changes at Mount Sanqingshan World Heritage Site, China. Environ. Manag. 2016, 57, 1024-1040. [CrossRef]

45. Kokaraki, N.; Hopfe, C.J.; Robinson, E.; Nikolaidou, E. Testing the reliability of deterministic multi-criteria decision-making methods using building performance simulation. Renew. Sustain. Energy Rev. 2019, 112, 991-1007. [CrossRef]

46. Velasquez, M.; Hester, P.T. An Analysis of Multi-Criteria Decision Making Methods. Int. J. Oper. Res. 2013, 10, 56-66.

47. Malczewski, J.; Rinner, C. Multicriteria Decision Analysis in Geographic Information Science; Dealing with uncertainties; Springer: Berlin/Heidelberg, Germany, 2015; pp. 191-221. ISBN 978-3-662-50152-8.

48. Saviano, M.; Di Nauta, P.; Montella, M.M.; Sciarelli, F. Managing protected areas as cultural landscapes: The case of the Alta Murgia National Park in Italy. Land Use Policy 2018, 76, 290-299. [CrossRef]

49. Sarraf, R.; McGuire, M.P. Integration and comparison of multi-criteria decision making methods in safe route planner. Expert Syst. Appl. 2020, 154, 1113399. [CrossRef]

50. Kabassi, K.; Virvou, M. Comparing Two Multi-Criteria Decision Making Theories for the Design of Web-based Individualised Assistance. In Proceedings of the 10th International Conference on Human Computer Interaction-HCII'2005); Lawrence Erlbaum Associates Publishers: Mahwah, NJ, USA, 2005.

51. Annette, J.R.; Banu, A.; Chandran, P.S. Comparison of Multi Criteria Decision Making Algorithms for Ranking Cloud Renderfarm Services. Arxiv Prepr. 2016, arXiv:1611.10204. [CrossRef]

52. Chitsaz, N.; Banihabib, M.E. Comparison of Different Multi Criteria Decision-Making Models, Prioritizing Flood Management Alternatives. Wat. Res. Manag. 2015, 29, 2503-2525. [CrossRef]

53. Erdoğan, N.K.; Altınırmak, S.; Karamaşa, Ç. Comparison of multi criteria decision making (MCDM) methods with respect to performance of food firms listed in BIST. Copernic. J. Financ. Account. 2016, 5, 67-90. [CrossRef]

54. Kolios, A.; Mytilinou, V.; Lozano-Minguez, E.; Salonitis, K. A Comparative Study of Multiple-Criteria Decision-Making Methods under Stochastic Inputs. Energies 2016, 9, 566. [CrossRef]

55. Hodgett, R.E. Comparison of Multi-Criteria Decision-Making Methods for Equipment Selection. Int. J. Adv. Manuf. Tech. 2016, 85, 1145-1157. [CrossRef]

56. Harris, S.; Nino, L.; Claudio, D. A Statistical Comparison between Different Multicriteria Scaling and Weighting Combinations. Int. J. Ind. Oper. Res. 2020, 3. [CrossRef]

57. Abounaima, M.C.; Lamrini, L.; EL Makhfi, N.; Ouzarf, M. Comparison by Correlation Metric the TOPSIS and ELECTRE II Multi-Criteria Decision Aid Methods: Application to the Environmental Preservation in the European Union Countries. Adv. Sci. Technol. Eng. Syst. J. 2020, 5, 1064-1074. [CrossRef]

58. Nemeth, B.; Molnar, A.; Bozoki, S.; Wijaya, K.; Inotai, A.; Campbell, J.D.; Kalo, Z. Comparison of weighting methods used in multicriteria decision analysis frameworks in healthcare with focus on low- and middle-income countries. J. Comp. Eff. Res. 2019, 8, 195-204. [CrossRef] [PubMed]

59. Anojkumar, L.; Ilangkumaran, M.; Sasirekha, V. Comparative analysis of MCDM methods for pipe material selection in sugar industry. Expert Syst. Appl. 2014, 41, 2964-2980. [CrossRef]

60. Calıskan, H.; Kursuncu, B.; Kurbanoglu, C.; Guven, S.Y. Material selection for the tool holder working under hard milling conditions using different multi criteria decision making methods. Mater. Des. 2013, 45, 473-479. [CrossRef]

61. Yergeau, M.E. Tourism and local welfare: A multilevel analysis in Nepal's protected areas. World Dev. 2020, 127, 104744. [CrossRef]

62. Yazdani, M.; Payam, A.F. A comparative study on material selection of microelectromechanical systems electrostatic actuators using Ashby, VIKOR and TOPSIS. Mater. Des. 2015, 65, 328-334. [CrossRef]

63. Kittur, J. Optimal Generation Evaluation using SAW, WP, AHP and PROMETHEE Multi-Criteria Decision Making Techniques. In Proceedings of the IEEE International Conference on Technological Advancements in Power \& Energy, Kollam, India, 24-26 June 2015; pp. 304-309.

64. Zyoud, S.H.; Fuchs-Hanusch, D. Comparison of Several Decision Making Techniques: A Case of Water Losses Management in Developing Countries. Int. J. Inf. Technol. Decis. Mak. 2019, 18, 1551-1578. [CrossRef]

65. Podawca, K.; Pawłat-Zawrzykraj, A. Diversifying Tourism in Municipalities within Impact Areas of National Parks. Pol. J. Environ. Stud. 2018, 27, 2213-2227. [CrossRef]

66. Singh, A.; Gupta, A.; Mehra, A. Best criteria selection based PROMETHEE II method. OPSEARCH 2020, 58, 160-180. [CrossRef]

67. Memariani, A.; Amini, A.; Alinezhad, A. Sensitivity Analysis of Simple Additive Weighting Method (SAW): The Results of Change in the Weight of One Attribute on the Final Ranking of Alternatives. J. Ind. Eng. 2009, 4, 13-18.

68. Pamučar, D.S.; Božanić, D.; Ranđelović, A. Multi-Criteria Decision Making: An example of sensitivity analysis. Serb. J. Manag. 2017, 12, 1-27. [CrossRef]

69. Kumar, R.; Dubey, R.; Singh, S.; Singh, S.; Prakash, C.; Nirsanametla, Y.; Królczyk, G.; Chudy, R. Multiple-Criteria DecisionMaking and Sensitivity Analysis for Selection of Materials for Knee Implant Femoral Component. Materials 2008, $14,2084$. [CrossRef] 
70. Abedi, M.; Torabi, S.A.; Norouzi, G.-H.; Hamzeh, M.; Elyasi, G.-R. PROMETHEE II: A knowledge-driven method for copper exploration. Comput. Geosci. 2012, 46, 255-263. [CrossRef] 